\title{
Consumption Pattern and Children Bullying Behavior in Social Media
}

\author{
Hedi Pudjo Santosa \\ \{hedipudjos@gmail.com\} \\ Universitas Diponegoro, Indonesia
}

\begin{abstract}
Survey on children internet consumption shows as many as 2064 children aged 9-12 years old have varied internet consumption purposes e.g., for studying, playing games, watching movies or video, using social media, e-commerce, reading news, downloading, and listening to music. One of many things that bring children closer to the internet today is the obligation from teachers to students to finish their assignments by accessing information from the internet. Unfortunately, there is also a lot of bullying happening in social media. Social media can influence a person's social behavior, including bullying. Social media has a big influence on bullying. This study aims to see how children's consumption patterns and forms of child bullying behavior on social media. This study uses a descriptive qualitative method to analyze social events, phenomena and circumstances. The pattern of media consumption is related to the information seeking behavior model, where this model explains that the use of information exists because of information needs, so that information searches are carried out.
\end{abstract}

Keywords: Media Consumption, Patterns, Bullying, Children

\section{Introduction}

According to YKBH data in 2015 in a survey of internet behavior on 2064 children aged 9-12 years old consisted of studying, playing games, watching movies or videos, playing social media, buying and selling, reading news, downloading, and listening to songs shows that despite the various positive impacts, the use of gadgets and the internet certainly has negative effects [1].

The Ministry of Communication and Informatics (Kominfo) in 2014 launched the results of a study which traced online activities from a sample of children and adolescents aged 10-19 years. The survey results yielded several facts, including:

1. At least 30 million children and adolescents in Indonesia are users of the internet and digital media;

2. The majority of respondents have used online media for more than a year and almost half of them admit to learning to surf the internet for the first time from friends;

3. There are about $20 \%$ of respondents who do not use the internet, the reasons are they do not have a device, there is no infrastructure to access the internet or they are prohibited by their parents;

4. The main motivations for children to access the internet are to seek information, connect with friends, and for entertainment;

5. Almost all respondents disagree with pornographic content, but a large number of children and adolescents have been exposed to pornographic content; 
6. Only a few parents are able to supervise their children in accessing the internet.

Unfortunately, parents are still not aware about cases of bullying or bullying on the internet, especially in social media.

Based on data from the Indonesian Child Protection Commission (KPAI), the number of educational cases as of May 302018 was 161 cases, of which it was revealed that data on children victims of violence and bullying reached 22.4 percent, and children perpetrators of violence and bullying reached 25.5 percent. From 2011 to 2016 , around 253 bullying cases were also found, consisting 122 children victims and 131 children perpetrators.

This data is not far different from the Ministry of Social Affairs which reported that up to June 2017, there were 967 cases with 117 cases of which were bullying. UNICEF in 2016 also reported that as many as 41 to 50 percent of adolescents in Indonesia between the ages of 13 and 15 have experienced cyber bullying. According to Koentjoro [2], a social psychologist from Gadjah Mada University (UGM) social media can influence a person's social behavior, including bullying. "Social media has a big influence in triggering bullying", he explained, as reported by the official UGM website [3].

Ideally, the use of gadgets for children should still be limited and accompanied by parents. However, in fact, the existence of restrictions on the use of gadgets makes children to be the victims of bullying by their playmates because they are considered not updated to the latest information. This is an interesting concern to be further examined on how children's media consumption in using gadgets, especially social media, is the form of bullying they receive. The aim of this research is to identify the form of media consumption by children and what forms of bullying do they receive when using social media.

\section{Technology Determinism}

The relations between technology, media, and society or what is often referred to as technological determinants, is an understanding that technology is determinant or determines in shaping human life. McLuhan's thinking that technology and engineering, information modes and communication codes play important roles is often referred to as media ecology [4]. The three assumptions of this theory are as follows:

First, the media influence every action or action in society. This first assumption emphasizes the idea that at this time humans cannot be separated from the media. Media is an important thing; it even penetrates into the deepest aspect of human life. The existence of the media has an influence on human life and society.

Second, the media improve perceptions and manage experiences. This second assumption explains how people are directly influenced by the media; where the media have great power in influencing our view of the world.

Third, the media binds the world together. The third assumption of media ecology theory states that the media binds the world together. To explain how the media binds the world into one global political, economic, social and cultural system, or what is called a global village.

From the three assumptions above, we can see how the development of technology will also affect the pattern and shape of a person in seeking information and human life in other fields where every kind of technology gives birth to a technological environment. This technological environment indirectly changes culture, social norms, interaction patterns, and community organizations.

One of the forms of this determination is social media. Social media can be interpreted as a form of interaction between a number of people through sharing information and ideas through 
internet networks to form virtual communities [5]. According to Liliweri [6], social media has the following characteristics:

1. Engaging. Social media has an engaging character, where it involves everyone who uses social media to share the best way to meet their wants and needs;

2. Empathy. Effective social communication requires the ability to place oneself in the hearts and minds of others. Where social media places a person to not only be a communicator, but also communicating and teaching the value of empathy;

3. Trustworthy. The ability to build honesty so that trust arises;

4. Unique. Where social media is unique, e.g., the existence of togetherness between the source and the recipient in shaping content;

5. Analytical. Encourages users to think analytically.

In addition, according to Kietzmann [6], the function of social media is akin to a beehive

that forms a network framework consisting of blocks related to one another. Some of the functions of social media include:

1. Identity, how by using social media we can reveal ourselves;

2. Conversation, how a block containing user activity communicates with other users;

3. Sharing, social media helps users distribute messages, receive messages, and exchange messages;

4. Relationship, shows the extent to which users can relate to other users;

5. Groups, groups in social media functionally show the extent to which users can form new communities, groups or even societies.

\section{Cyber Bullying}

Bullying is a complex phenomenon and manifests in different forms according to changes that occur in society. The development of the media has changed the forms of bullying, one of which is bullying in cyber media. According to Willard Yand quoted by Bernike in Santosa [7], that there are several forms that are categorized as cyber bullying:

1. Flaming, is a form of online fighting that uses electronic messages with angry and vulgar language;

2. Harassment, is a form of harassment by sending messages repeatedly with malicious, cruel and insulting messages;

3. Denigration, is defamation, which is a form of bullying in the form of sending statements or certain materials online that are harmful, untrue, or rude about someone to another;

4. Impersonation (incognito) is virtual bullying in which the perpetrator pretends to be someone else and sends or posts material that makes someone have a bad reputation;

5. Outing, is cyber bullying by sending or uploading material containing someone's personal, sensitive or embarrassing information, including forwarding personal messages or pictures with the same content of message;

6. Trickery, doing trickery or when talking to someone with the aim of obtaining information to reveal embarrassing and confidential information and then spread it by sharing it online;

7. Exclusion, namely bullying carried out by means of removing or removing someone roughly from an online group;

8. Cyber stalking, degrading other people with electronic media so that victims feel helpless and experience significant fear. 


\section{Methodology}

This research is a qualitative study using a phenomenological research approach. The phenomenological approach is a view that focuses on subjective human experiences. The subjects of this study were elementary school children and their parents (father or mother) using the internet as access to information and using messengers.

Esterberg [8] states that in conducting interviews a question instrument should be prepared firsthand and each respondent gets the same question. The steps used in this study are as follows: looking for problems and formulating questions, creating descriptive narratives, describing the results of interviews, and analyzing data in the form of implications and interpretations [9].

\section{Results and Discussion}

This research was conducted in two stages, namely distributing questionnaires to see how the children's consumption patterns were shaped. The results of the questionnaire are as follows:

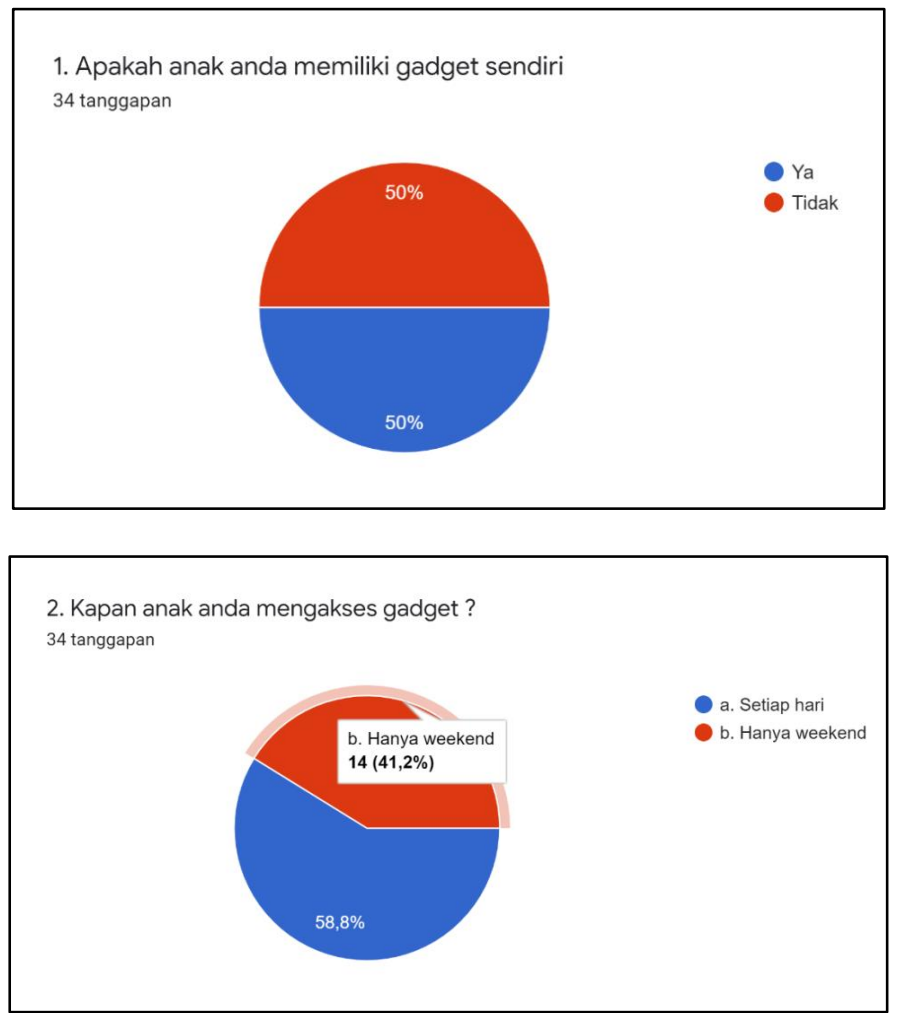



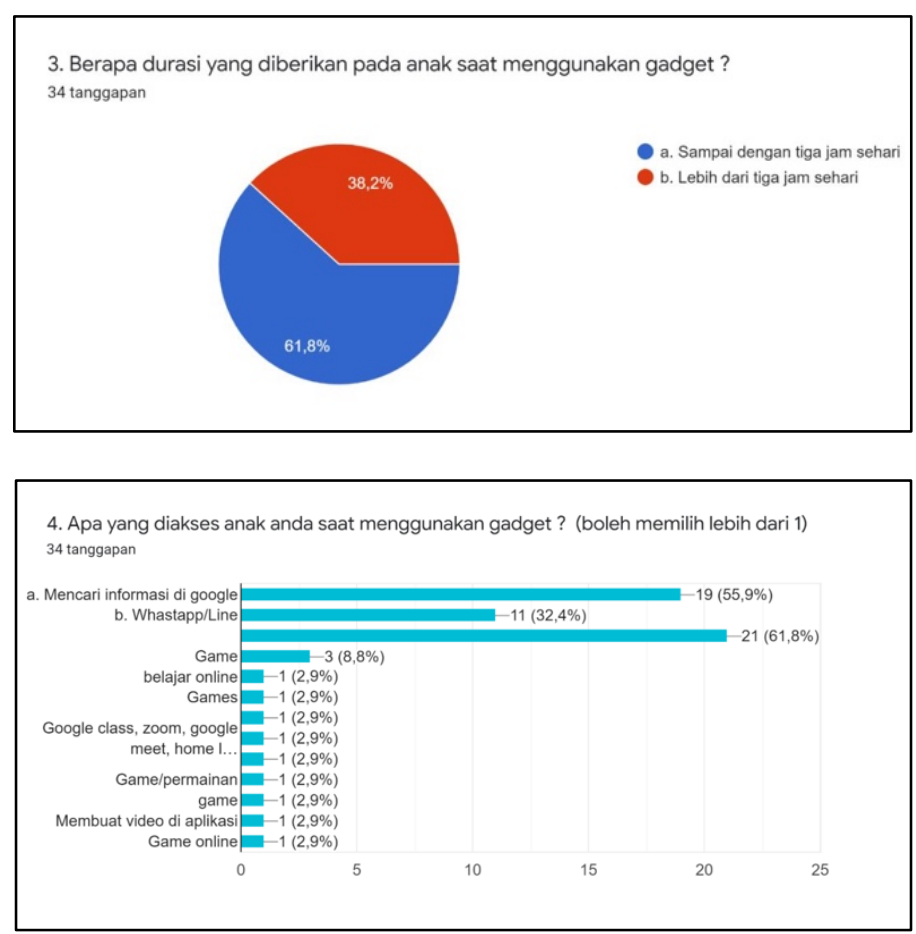

5. Apakah anak anda mengetahui mengenai bullying atau cyber bully? 34 tanggapan

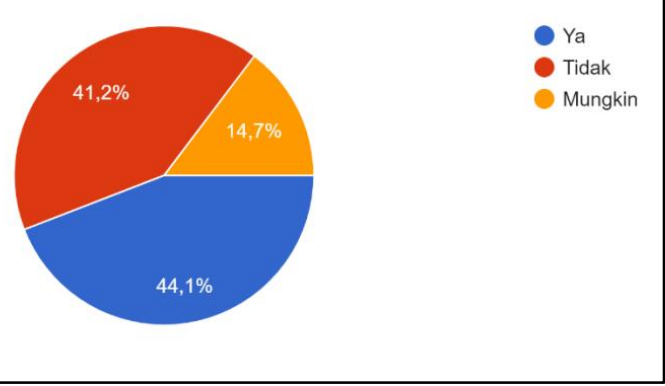

To get more in-depth results, the researchers conducted in-depth interviews with three parents as follows:

\begin{tabular}{|l|l|l|l|l|}
\hline No & Nama Orang Tua & Pekerjaan & $\begin{array}{l}\text { Jenis kelamin anak/ } \\
\text { usia }\end{array}$ & \\
\hline 1 & Diska Rahmita & Ibu RT & Laki-laki / 11thn & Informan 1 \\
\hline 2 & Windu Indarweni & Swasta & $\begin{array}{l}\text { Perempuan/ 11thn } \\
\text { dan 8 thn }\end{array}$ & Informan 2 \\
\hline 3 & Gina Lola Lasut & Ibu RT & Perempuan/ 12 thn & Informan 3 \\
\hline
\end{tabular}


The pattern of media consumption is related to the information seeking behavior model, where this model explains that the use of information exists because of information needs, so that information searches are carried out.

\section{References}

[1] Nabilla, "Mewujudkan Kolaborasi Keluarga, Pemerintah, dan Duta Kekinian untuk Menunjang Pendidikan di Era Digital," www.bundabiya.com, 2018. .

[2] K. Soeparno, "Social psychology: The passion of psychology," Bul. Psikol., vol. 19, no. 1, 2011.

[3] Kumparan, "Psikolog: Media Sosial Bisa Memicu Perilaku Bullying," Kumparan, 2019. [Online]. Available: https://kumparan.com/millennial/psikolog-media-sosial-bisa-memicu-perilakubullying-1qs5OBafutX/full.

[4] R. West and L. H. Turner, Introducing Communication Theory: Analysis And Appliaction. McGraw-Hill Education, 2018.

[5] T. Ahlqvist, A. Bäck, M. Halonen, and S. Heinonen, "Social media roadmaps: exploring the futures triggered by social media," 2008.

[6] A. Liliweri, Komunikasi Antar-Personal. Jakarta: Kencana., 2015.

[7] H. P. Santosa, "Buku Ajar Mata Kuliah Sosiologi Komunikasi," in EF Press Digimedia, Semarang, 2017.

[8] K. G. Esterberg, Qualitative methods in social research, no. 300.18 E8. 2002.

[9] R. Von Eckartsberg, "Introducing existential-phenomenological psychology," in Phenomenological inquiry in psychology, Springer, 1998, pp. 3-20. 